\title{
Rhizobacteria and their metabolites as a promising green approach for the treatment of pesticide contaminated agricultural soils
}

\begin{abstract}
Pesticides are employed to control and manage pest populations at tolerable levels. Pesticides are classified especially according to their chemical structure, toxicity, environmental persistence and target organisms. The massive use of these pollutants in addition to their toxic potential seriously threatens ecosystems and humans. For this reason, the development of green bioremediation processes is necessary. The ability of several microorganisms to bioremediate pesticides is mainly based on their biodegradation activity. Though bacteria have been proved to be efficient biodegraders and bioremediators, some fungi and archae could biodegrade recalcitrant pesticides too. The bioremediation of pesticide-contaminated agricultural sites may be optimized by considering the prevalent environmental conditions, the microorganisms that solubilize and degrade the pesticides most effectively, the variables that affect the biodegradation rate and the chemical structure of pesticides. This chapter explores the importance of pesticides as persistent organic pollutants in agricultural soils, particularly in the plants rhizospheric area and further illustrates the recent advances in pesticide microbial bioremediation, with emphasis on the metabolic potential of pseudomonads as a representative model of pesticide-degrading microorganisms.
\end{abstract}

Keywords: pesticides, agricultural soils, rhizospheric area, toxicity, bioremediation, pseudomonas, enzymes, biosurfactants
Volume 5 Issue 6 - 2020

\author{
Wafa Hassen, ${ }^{1,2}$ Hanene Cherif, ${ }^{2}$ Yasmine \\ Souissi, ${ }^{2}$ Noura Raddedi, ${ }^{3}$ Mohamed Neifar, ${ }^{2}$ \\ Ameur Cherif \\ 'Research Unit of Analysis and Process Applied to the \\ Environmental,APAE Higher Institute of Applied Sciences and \\ Technology Mahdia, University of Monastir, Tunisia \\ ${ }^{2}$ LR Biotechnology and Bio-Geo Resources Valorization \\ (LRI IES3 I), Higher Institute for Biotechnology, University of \\ Manouba, Biotechpole of Sidi Thabet, Tunisia \\ ${ }^{3}$ Department of Civil, Chemical, Environmental and Materials \\ Engineering (DICAM), University of Bologna, Italy
}

\begin{abstract}
Correspondence: Dr.Wafa Hassen, Research Unit of Analysis and Process Applied on the Environmental-APAE UR I7ES32, Higher Institute of Applied Sciences and Technology Mahdia "ISSAT", University of Monastir, 5100 Mahdia, Tunisia, Tel 00216-22931899, Email hasen.wafa@gmail.com
\end{abstract}

Received: August 3I, 2020 | Published: December 08, 2020

\section{Introduction}

Pesticides are world-wide used. Despite the inbalance of use between developed and under developed countries, they still present a major environmental and health concerns. During the last $40 y e a r s$, in modern agriculture, a large number of pesticides were used to control insect pests and to enhance crop production. ${ }^{1,2}$ Their excessive and unreasonable use causes stress and yield losses in addition to the degradation of soil quality. ${ }^{3,4}$ Moreover, these chemicals are spread in the environment due to their adhesion to the organic matter in the soil and/or to the plant roots. They highly contaminate soil ecosystems and cause a serious threat to the balance among various groups of microorganisms and the soil components. In the meanwhile, the widespread application of these pesticides disturb the rate and the activity of soil enzymes.

Pesticides are degraded in the environment, principally by the action of microorganisms or their enzymes. ${ }^{6}$ After a long-term exposure to these pesticides, some microorganisms can develop resistance and can successfully be used for bioremediation of pesticide-contaminated soils. ${ }^{7,8}$ Some microbes exhibited an efficient bioremediation potential in the presence of specific pesticides using them as a source of nutrients and energy. ${ }^{9,10}$

In order to predict the fate of pesticides in soils, it is important to have an understanding of those microbes able to degrade pesticides, their activities and the factors that improve their activity in situ. ${ }^{9}, 11$ Bacteria belonging to the genus Pseudomonas are reported to be metabolically adaptable and able to degrade several organic or inorganic substances such as aromatic hydrocarbons, oil, petroleum products and pesticides. ${ }^{12,13}$ This genus forms an heterogeneous group of bacteria, present in large numbers in the rhizosphere where they are active in the mineralization of organic matter. ${ }^{14}$ Moreover, Pseudomonas possesses a variety of diverse catabolic pathways that enable them to metabolize a diverse range of low-molecularweight compounds. ${ }^{15}$ Due to the ubiquity and versatility of these Pseudomonads, there is a considerable interest in exploiting these bacteria for diverse agricultural applications. Moreover, these bacteria represent suitable candidates for bioremediation applications. This review gives an overview on the relationship between the pesticide application in agricultural fields and their biodegradation routes. Therefore, the role of rhizospheric Pseudomonas in pesticides biodegradation and their practical application for bioremediation of agriculture contaminated soils will be described.

\section{Pesticide use in agriculture field}

In modern agriculture, millions of tons of pesticides are applied annually to enhance the production through controlling harmful effects caused by several organisms, including insects, fungi, bacteria, viruses as well as weeds. ${ }^{16}$ The first use of pesticides in agriculture dates back to antiquity. ${ }^{17}$ Their development and their extensive use were then concomitant with inorganic chemistry development. The compounds employed are derivatives of inorganic compounds as examples, those based on arsenic, copper, zinc, manganese or nicotine sulfate. Then, from the Second World War, pesticides have benefited from the development of organic chemistry. ${ }^{18}$ The development of synthetic compounds was also responsible for the rapid expansion of pesticides use from 1940. ${ }^{19}$ A slowing trend has been observed since the ' 80 s, partly due to the discovery of more active substances requiring lower tonnages. In addition, this regression was also due to serious ecological and toxicological problems associated with some of these substances. Pesticides are characterized by a large variety of 
chemical structures, functional groups and diverse activities. That is the reason why their classification is complex..$^{20,21}$ In the frame of the actual agricultural practices, manufacturers and users classify them according to the target species. We can thus distinguish herbicides, insecticides, fungicides, etc. ${ }^{22}$ Another classification is made according to the chemical nature of the main active substance. We can cite as examples organochlorines, organophosphates, carbamates, pyrethroids, triazines, etc. ${ }^{23,24}$ A large variety of pesticides is available on the market. Some examples are presented in Table 1 where specific characteristics such as chemical family, type, structure, toxicological classes and pesticide half-life are reported. . $^{2,25,26}$ Recently, organophosphorus pesticides were classified as the most worldwide used group. ${ }^{27} \mathrm{~A}$ large number of organochlorine pesticides were prohibited due to their persistency and accumulation in soil. ${ }^{28}$ More than 100 organophosphorus pesticides are in use, accounting for about $38 \%$ of total pesticide usage. ${ }^{29}$

Table I Characteristics of the most used pesticides in agriculture practices. ${ }^{21,25}$

\begin{tabular}{|c|c|c|c|c|c|}
\hline Active substance & Chemical family & Chemical type & Chemical structure & Toxological class & Half-time (days) \\
\hline Aldrin & Organochlorine & Insecticide & & Highly hazardous & 365 \\
\hline Chlordane & & Insecticide & & $\begin{array}{l}\text { Moderately } \\
\text { hazardous }\end{array}$ & 350 \\
\hline DDT & & Insecticide & & $\begin{array}{l}\text { Moderately } \\
\text { hazardous }\end{array}$ & 2000 \\
\hline Dieldrin & & Insecticide & & Slightly hazardous & 2000 \\
\hline Endosulfan & & Insecticide & & $\begin{array}{l}\text { Moderately } \\
\text { hazardous }\end{array}$ & 50 \\
\hline Lindane & & Insecticide & & $\begin{array}{l}\text { Moderately } \\
\text { hazardous }\end{array}$ & 400 \\
\hline Pentachlorophenol & & Insecticide & & Highly hazardous & 48 \\
\hline Chlorpyrifos & Organophosphate & Insecticide & & $\begin{array}{l}\text { Moderately } \\
\text { hazardous }\end{array}$ & 30 \\
\hline
\end{tabular}


Table Continued.

\begin{tabular}{|c|c|c|c|c|c|}
\hline Active substance & Chemical family & Chemical type & Chemical structure & Toxological class & Half-time (days) \\
\hline Diazinon & & Insecticide & $\begin{array}{l}\mathrm{H}_{3} \mathrm{CH}_{2} \mathrm{CO} \text { - } \\
\mathrm{H}_{3} \mathrm{CH}_{2} \mathrm{CO}^{\prime}\end{array}$ & $\begin{array}{l}\text { Moderately } \\
\text { hazardous }\end{array}$ & 40 \\
\hline Dimethoate & & Insecticide & $\begin{array}{l}\mathrm{H}_{3} \mathrm{CO} \\
\mathrm{H}_{3} \mathrm{CO}\end{array}$ & $\begin{array}{l}\text { Moderately } \\
\text { hazardous }\end{array}$ & 7 \\
\hline Phorate & & Insecticide & & $\begin{array}{l}\text { Extremely } \\
\text { hazardous }\end{array}$ & 60 \\
\hline
\end{tabular}

In Tunisia, the Pesticide Registration Service announced that the pesticides annual imports average are around 5000 tonnes/year. ${ }^{30}$ And their use continues to progress (Figure 1); in 2010 it was 3182.1tons, in 2013 it increased to 4113.9tons and finally, in 2016, it is in the order of 6661.9 tons. These quantities of pesticides were imported as active ingredients or as formulations, and were mostly used in agriculture sector (around 95\%) in a treated area of approximately
761,000 hectares/year and about $5 \mathrm{~kg} /$ hectares. According to the list of pesticides approved in Tunisia by the Pesticide Registration Service, ${ }^{31}$ 732 active ingredients and 849 products were marketed on the local market. Among these pesticides, Fungicides represent 59\% of total pesticides imported in Tunisia with 433 products and 359 active ingredients, followed by Herbicides (22\%) and Insecticides (17\%) (Figure 1).

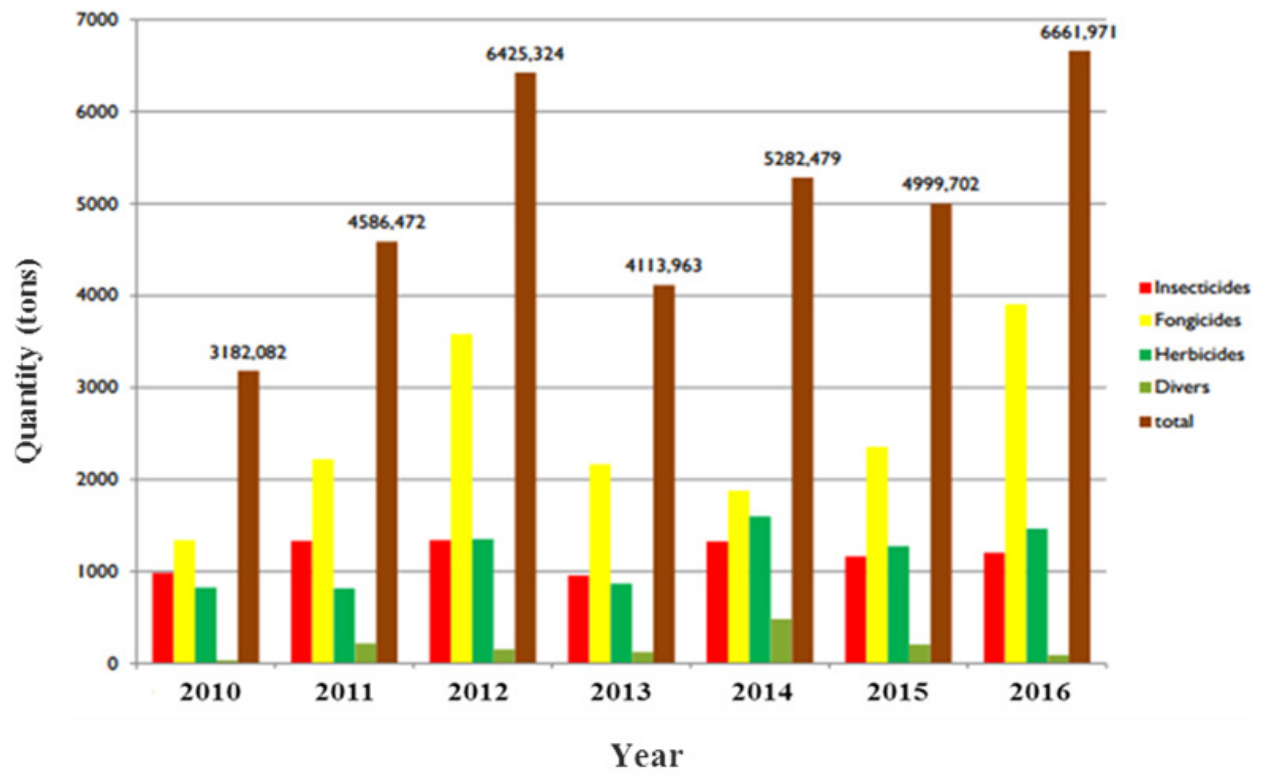

Figure I The quantities of pesticides imported in Tunisia. ${ }^{30}$

\section{Environmental impact of pesticides}

\section{Factors influencing the mobility or persistence of pesticides in the rhizosphere}

The mobility of pesticides can lead in their redistribution within the application site or the displacement of a part of their quantity of site. ${ }^{32}$ The persistence of an applied molecule in the rhizosphere is determined by its dissipation, which is the result of all phenomena determining the quantity of substances present in a given compartment at a given moment. It is influenced by many factors, including degradation, sorption and bioavailability as outlined by Arias-Estevez et al. ${ }^{33}$

Pesticides application method depends on the type of formulation. Usually, they are sprayed on crops and cover the aerial parts of the plants and soil. ${ }^{34}$ They could also be incorporated into the soil. A large fraction of pesticides seeps into the soil and reaches surface waters and groundwater. An important part of pesticides are found in the atmosphere under the action of various physicochemical or climatic events.. This contamination is also related to the method of application due to pesticide volatilization, wind drift during spraying and wind 
erosion of soil particles on which pesticides are adsorbed. ${ }^{35}$ The amounts of chemical products administered vary according to several important factors such as product activity, pesticide persistence, crop type and period of growth. The treatments can be unique to a certain stage of crop growth or fraction. In the latter case, this treatment may range in pre-sowing, pre-planting, pre- or post-emergence. The same culture can receive several treatments all over the year. ${ }^{36,37}$

The behavior of pesticides in soil is governed by a variety of complex processes. ${ }^{33,38}$ Depending on the process, the concentration and the form of the molecule vary in the environmental matrices. The pesticide fate in the environment is thus estimated through its half-life referred as DT50. The DT50 is the times taken for the degradation or dissipation of $50 \%$ of the amount initially applied. ${ }^{39}$ DT50 values are usually used to estimate pesticide persistence. Nevertheless, for the same molecule, the observed DT50 values can present a wide range of values illustrating the influence of the variability of climate conditions, soil type and cropping practices. ${ }^{40}$ The processes that control the transport of pesticide in soil to other environmental compartments are mainly biological and/or chemical degradation, sorption, desorption phenomena, ${ }^{41,42}$ volatilization, runoff, leaching and plant uptake. ${ }^{43}$ The relative importance of these processes varies according to the chemical nature of the applied molecules, to soil characteristics and to the climate (Figure 2). The retention routes and the degradation processes of pesticides in soil are the two fundamental phenomena conditioning their environmental fate. ${ }^{33,44}$

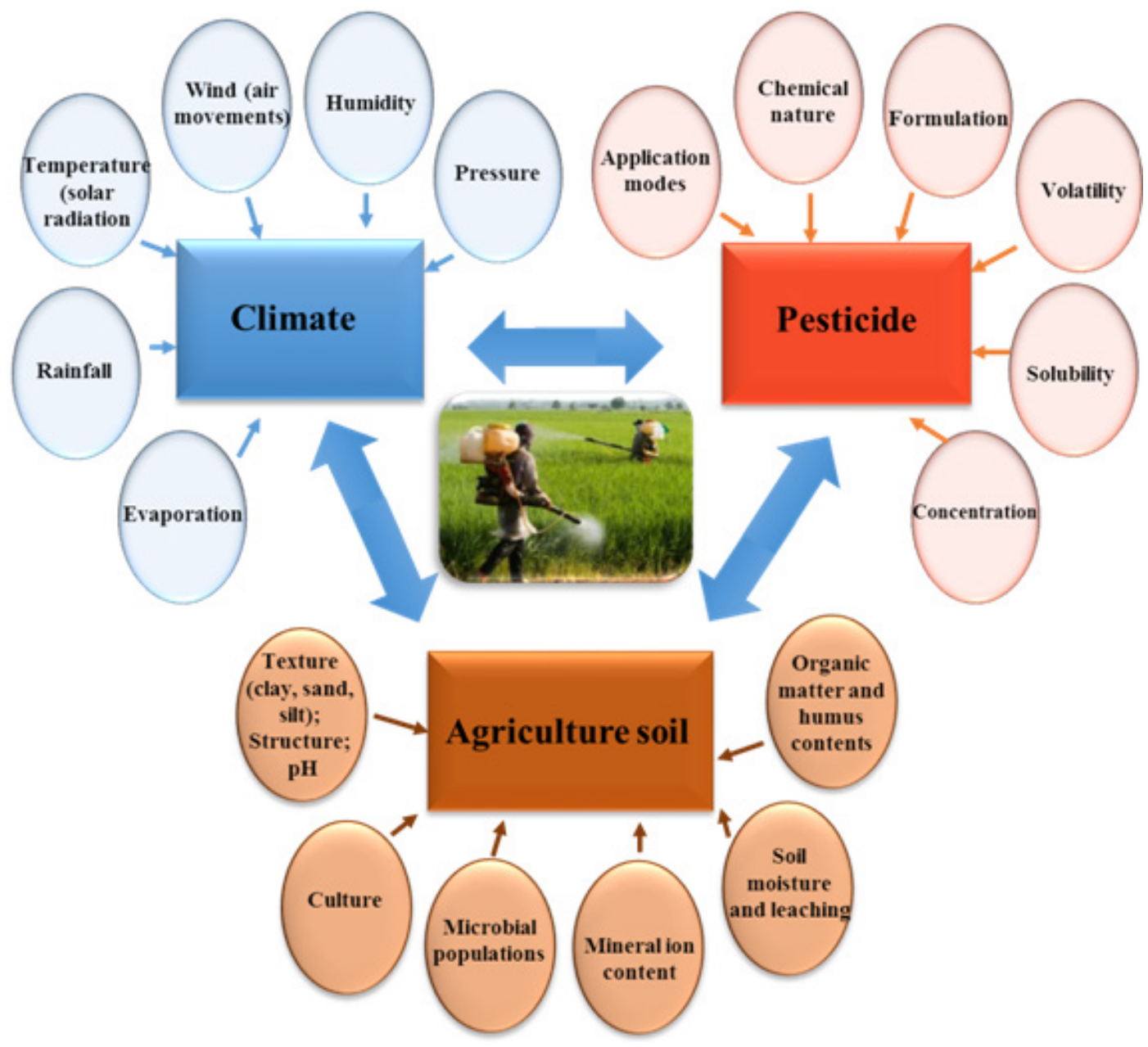

Figure 2 Factors influencing the fate of pesticides in agricultural soil.

Degradation is essential to decrease the amount of residues in soil. It is controlled by abiotic and biotic factors and involves interactions between the different constituents of the soil, microorganisms and pesticide molecules. ${ }^{45}$ Abiotic transformations are caused by chemical reactions that are not catalyzed by enzyme systems. The principal abiotic transformations are the reactions of oxidation, reduction, conjugation, hydrolysis, and photoreactions. Biotic degradation is due to the action of various living microorganisms that chemically transform molecules through their enzymatic systems. The main mechanisms of degradation by microorganisms are the direct metabolism, the cometabolism as well as conjugation and condensation reactions. ${ }^{44,46}$ In addition, retention phenomena play a fundamental role in the fate of pesticides in soils, especially in their persistence. ${ }^{33}$ They correspond mainly to adsorption, transfer of a compound from the liquid or gaseous phase from the soil to the solid phase, and conversely to desorption. The adsorption is a more or less reversible phenomenon depending on numerous parameters. The content of soil organic matter is a major factor influencing the retention of pesticides on solid soil phase. A positive correlation was observed for the majority of pesticides between retention and content of soil organic matter. ${ }^{47}$ The $\mathrm{pH}$, clay, soil oxides also influence retention. ${ }^{4}$ 
Retention and degradation are closely related. ${ }^{22}$ Retention decreases the accessibility of compounds to soil microorganisms, reducing their degradability. This coupling retention/degradation allows the determination of substance mobility. The generation of non-extractable pesticide residues are due of two mechanisms that are (I) the formation of covalent bonds between the molecules and the organic material and (II) the sequestration of molecules and/or its degradation products. Organic matter is the key factor of their training. Other factors can influence their formation, such as $\mathrm{pH}^{48}$ and time. ${ }^{49}$ The formation of these residues is often considered as a dissipation pathway contributing to the elimination of soil pesticides, decreasing the availability to degradation..$^{50}$ However, this stabilization is not definitive in time and could be the origin of a very diffuse pollution and deferred in time..$^{22,48}$ The significant presence of residues throughout the food chain is responsible for biodiversity reduction and ecological disruption. This is largely due to bioaccumulation of these substances. Moreover, the multiplication of pesticide treatments has the effect of favoring the appearance of resistance among the targeted organisms (insects, mites,...), which involves the use of increasingly massive doses and more dangerous products. In this case, these products may present associated toxicity risks to biota that were not affected by treatment. ${ }^{51}$

\section{Pesticide and their derivates toxicity}

Pesticides are appearing beneficial in terms of crop quality and productivity, but their harmful side effects were quickly shown. The effect of these pesticides depends of their mode of action as some are more toxic than others, their persistence over time as some degrade much more rapidly than others and their degradation products that could be more toxic and degrades less quickly than the parent molecule. ${ }^{52}$ Amongst the most alarming problems associated with pesticide application is their possible toxicological impact in the environment. Therefore, their possible incorporation into the food chain affects ecosystems and human beings. ${ }^{53}$ Thus, 15 to $20 \%$ of these chemicals are considered as carcinogens ${ }^{54}$ and most of them are recognized as endocrine disruptors. ${ }^{55}$ Another important issue is the effects produced due to the combination of several active substances, which are, generally, superior to individual effects of substances due to the interaction between simultaneously present molecules. ${ }^{56}$ According to the literature, Odukkathil and Vasudevan ${ }^{51}$ reported that pesticide degradation products could also be toxic or even more toxic and more mobile than the original molecule. For example, derivatives of Chlorpyrifos and Malathion were at least 100 times more toxic than the parent compounds and diazinon derivatives are 10 times more toxic..$^{57}$ In addition, when the pesticides are not used within the given time of their efficacy, they become obsolete. They are decomposed into other chemical components, which sometimes become even more toxic than the original pesticides ${ }^{58}$ Moreover, many pesticides used in agriculture contain in their formulation adjuvants with active substances that cause serious hazards. We can cite as an example, Dimethoate EC40, containing $400 \mathrm{~g} / \mathrm{L}$ of Dimethoate active ingredients as well as coformulants such as cyclohexanone, xylene and surfactants. ${ }^{59}$ These components are more dangerous than the active substance and causes serious clinical problem with a fatality rate estimated at of $20.6 \% .^{60}$

Several studies reported that pesticides are cytotoxic, neurotoxic, embryos toxic, mutagenic, teratogenic and carcinogenic. . $^{36,61-63}$ Pesticides can undergo metabolic activation and form electrophilic intermediates able to interact with nucleic acids. Other indirect ways of activation could be observed such as oxidative stress, inhibition of intercellular communication or formation of activated receptors. ${ }^{64}$ Some pesticides and their degradation products have also been identified as agents that could affect male fertility. ${ }^{62}$ An exposure to certain substances also could cause a disorder of the immune system. ${ }^{63}$ Salameh et al. ${ }^{61}$ reported that chronic exposure to pesticides was associated with symptoms of chronic respiratory diseases in children, especially asthma. Insecticides are reported as the most acutely toxic class of pesticides compared to herbicides and fungicides. ${ }^{36} \mathrm{~A}$ toxicology reference center in Tunisia has shown that intoxication by organophosphorus represents $11 \%$ of all acute intoxication. ${ }^{65}$

\section{Role of rhizospheric Pseudomonas in pesticide degradation}

Many studies focused on pesticide bioremediation due to the reported harmful impact on the environment and associated toxicity effects. Microbial biodegradation was reported as an essential mechanism and an effective biotechnological approach for the dissipation of pesticides in the environment. ${ }^{35,66}$

Bioremediation is a process used by microorganisms to convert pollutants into less or non-toxic compounds. Microbial pesticide bioremediation can be performed in situ or ex situ. ${ }^{6,67}$ There are two types of bioremediation: intrinsic bioremediation and enhanced bioremediation. ${ }^{68}$ The intrinsic bioremediation relies on bacteria that are already present in the soil. Enhanced bioremediation also known as bioaugmentation uses a bacterial consortium selected for its ability to transform contaminants. If the appropriate microorganism is absent or if biodegrading microbial population was reduced due to the toxicity of pesticides, in that case a specific microorganism or an appropriate consortium can be introduced into the soil to enhance the activity of the existing population and their degradation activity. ${ }^{67}$ These microorganisms could be either natural or genetically modified. ${ }^{69}$ The adaptive capacities of microorganisms to pesticide are explained by their ability to express enzymatic tools via genetic changes such as mutations, endogenous rearrangements or acquisition of exogenous DNA fragments by plasmids. ${ }^{70}$ In general, the metabolism of the limited number of synthetic pesticides can be achieved by a single strain, but frequently consortia of microorganisms are necessary for complete degradation. ${ }^{11,71}$ The biodegradation can be considered as an interesting alternative to physical and chemical methods because it is an eco-friendly and highly efficient approach. Moreover, it may be faster, safer, less expensive and can selectively achieve the complete destruction of organic pollutants. ${ }^{72}$

Pesticide degradation is dependent on the presence of relevant bacteria, which possess the appropriate enzymatic capabilities. The degradation rates are also strongly influenced by a wide variety of environmental factors including soil type, moisture content, temperature and $\mathrm{pH} .{ }^{73}$ The rhizosphere is the narrow region of soil that is directly influenced by root secretions and associated soil microorganisms. In that particular environment, the activity of these microorganisms is enhanced and may play a significant role in pesticide degradation. ${ }^{74}$ For example, P-nitrophenol hydrolysis product of parathion was mineralized more rapidly in rhizospheric soils than in non-rhizospheric soils. ${ }^{75}$ Pesticide degrading microorganisms are endowed with plant growth-promoting activities such as the production of plant growth hormones, biological nitrogen fixation, phosphate solubilization, siderophore and antagonistic properties which playing a key role in the sustainable agriculture. ${ }^{11,76}$ However, the fast disappearance of pesticide from rhizosphere soils can be attributed to the interaction of different bacteria such as PGPR (plant growth-promoting rhizobacteria) and PGPB (plant growthpromoting bacteria).$^{77}$ Their ability to degrade pesticide is an important phenomenon through which these chemicals are eliminated from the environment or transformed to less toxic products (metabolites). 
Furthermore, much attention has recently been paid on bioremediation of contaminated soils with PGPR. ${ }^{78,79}$ Several studies highlighted the taxonomic diversity of pesticide degrading bacteria including strains of the genera Flavobacterium, Xanthomonas, Enterobacter, Ochrobactrum, Rhododoccus, Agrobacterium, Arthrobacter, Burkholderia, Bacillus, Pseudomonas, etc. ${ }^{66,80}$ Particularly, members of Pseudomonas genera have been the most extensively studied. Their metabolic versality and diversity make them key players in the depollution of the environment. ${ }^{11,12,15,81}$ P. putida KT2440 and $P$. fluorescens, identified as rhizospheric bacteria, were reported as useful for the degradation of several pollutants in the root zone and can even reach deep soil layers. ${ }^{12}$ Other Pseudomonas species endowed with pesticide degrading abilities and islated from pesticide contaminated agricultural soils are summarized in Table 2.

\section{Enzymatic degradation of pesticides}

The bioremediation process depends on the metabolic potential of microorganisms to detoxify or transform the pollutant molecule using their enzymatic systems. Complete biodegradation of pesticides involves the phenomenon of oxidation by transforming the parent compound into carbon dioxide and water. This process provides both carbon and energy for the microorganism's growth. ${ }^{68}$ Each degradation step is catalyzed by specific enzymes involved in the hydrolysis of P-O, P-F, P-S and P-C bonds. ${ }^{5,29,82}$ The enzymatic activities play an important role because all biochemical transformations are related to the presence of enzymes such as hydrolases, peroxidases, oxygenases, and others. ${ }^{6,12,83}$ They are indicators of biological equilibrium and changes in the biological status due to soil pollution. These enzymes are produced during different metabolic pathways by degrading cells or are found outside to the cell. Thus the lack of the appropriate enzyme in the soil will stop the process of pesticide degradation which could strengthen the persistance of the pesticide. ${ }^{5}$ The lack of these enzymes is one of the common reasons for the pesticide persistence. The organophosphate (OP) compound biodegradation has been widely studied and several studies describing OP degrading enzymes are reported ${ }^{29,66}$ such as cabroxylesterases and phosphodiesterase. ${ }^{84}$ The enzymatic degradation is the most important strategy for removing pesticides compared to non-enzymatic processes. ${ }^{80}$ Hydrolases are among the major group of enzymes commonly used in pesticide bioremediation. These enzymes catalyze the hydrolysis of several major biochemical classes of pesticides having esters, peptide bonds, carbon halide bonds, tri-esters, urea, etc. Generally, they are functioning in the absence of redox cofactors making them ideal candidates for current bioremediation strategies. ${ }^{85}$

Table 2 Pesticide degrading Pseudomonas origin and degrading ability

\begin{tabular}{|c|c|c|c|c|c|c|}
\hline Pseudomonas species & Origin & Pesticide & $\begin{array}{l}\text { Rate of } \\
\text { degradation (\%) }\end{array}$ & Medium & Duration (h) & References \\
\hline Pseudomanas sp. & Rhizospheric soil & Quinolphos & 91.2 & Liquid & 192 & 81 \\
\hline Pseudomanas. sp. & Soil & DDT & - & Liquid & 96 & 108 \\
\hline Pseudomanas sp. & Soil & Aroclor 1242 & 99.8 & Liquid & 168 & 6 \\
\hline Pseudomanas sp.WBG3 & Soil & Methyl parathion & 95 & Soil & 168 & 109 \\
\hline Pseudomanas sp. & Agricultural soil & Diazinon & $80-92$ & Liquid & 336 & 2 \\
\hline Pseudomanas sp. & Agricultural soil & $\begin{array}{l}\text { HCN (Hexachloro- } \\
\text { cyclohexane) }\end{array}$ & - & Liquid & - & 110 \\
\hline \multirow[t]{2}{*}{ Pseudomanas putida } & Rhizospheric soil & Fenamiphos & 100 & Liquid & 96 & 111 \\
\hline & & & 100 & Soil & 192 & \\
\hline Pseudomanas putida SI 48 & Agricultural soil & Pentachlorophenol & 91 & Liquid & 168 & 112 \\
\hline \multirow[t]{2}{*}{ Pseudomanas putida } & coffee cultivated soil & Endosulfan & 70 & Liquid & 480 & 113 \\
\hline & & Endosilfan sulfate & 90 & Liquid & 504 & \\
\hline Pseudomanas putida & Soil & Dimethoate & 100 & Liquid & 96 & 114 \\
\hline Pseudomanas aeruginosa MCMB-427 & Sugarcane rhizosphere & Dimethoate & 90 & Liquid & 192 & 115 \\
\hline \multirow[t]{2}{*}{ Pseudomanas aeruginosa } & Soil & Chlorpyriphos & $75-87$ & Liquid & 480 & 116 \\
\hline & & & 89 & Soil & 720 & \\
\hline Pseudomanas aeruginosa & Soil of cotton field. & Endosulfan & 96 & Liquid & 288 & 117 \\
\hline Pseudomanas aeruginosa SI & Rhizosphere soil & Glyphosate & 99 & Soil & 120 & 118 \\
\hline \multirow[t]{2}{*}{ Pseudomanas fluorescence } & Soil & Chlorpyrifos & $75-87$ & Liquid & 480 & 116 \\
\hline & & & 89 & Soil & 720 & \\
\hline Pseudomanas stutzeri SI & Soil & Beta-cyfluthrin & 94 & Liquid & 192 & 119 \\
\hline Pseudomanas mendocina & Black cotton soil & Monocrotophos & 73 & Liquid & 192 & 120 \\
\hline Pseudomanas brassicacearum & Agricultural soil & Endosulfan & 98 & Liquid & 360 & 121 \\
\hline Pseudomanas azotoformans & Agricultural soil & Endosulfan & 82 & Liquid & 360 & 121 \\
\hline Pseudomonas pili BGI & Soil & Diazinon & - & Liquid & 288 & 122 \\
\hline
\end{tabular}


The laccase (benzenediol: oxygen oxidoreductase, EC 1.10.3.2) is one of the best-known multicopper enzymes and they have been detected in a variety of organisms such as bacteria, fungi, plants, and insects. ${ }^{86}$ Mostly, they are extracellular and nonspecific so they have the ability to oxidize a wide variety of aromatic and nonaromatic compounds which are used as hydrogen donors. The laccases have received particular interest in bioremediation applications of treated agriculture soil because they are biodegradable, cost-effective and environmentally friendly. These enzymes are successful at breaking down the complex structures of many pesticides. ${ }^{87-89}$ The laccase enzymatic activity has been discovered in a small number of bacteria. Some of them were found in P. maltophila, P. syringae, P. fluorescens GB1, P. putida GB1, P. desmolyticum NCIM 2112, P. sp. ${ }^{86}$ These bacterial laccases have the ability to perform the activity at crucial conditions like in the presence of high salt concentrations and even at alkaline $\mathrm{pH}$ values. ${ }^{90}$ Furthermore, these enzymes can be produced at large scale and can be purified and used for cell-free enzymatic transformation of pesticides. ${ }^{91}$

Several studies reported the successful and effective degradation of many pesticides catalyzed by the oxidative enzyme laccase in the presence of a reaction mediator (a laccase/mediator system). The results of Maruyama et al. ${ }^{87}$ showed that over $90 \%$ of dymron was degraded in $24 \mathrm{~h}$ in the presence of ABTS $\left(2.2^{\prime}\right.$-azino-bis [3ethylbenzthiazoline-6-sulphonic acid]), which is used as a mediator rather than by using only laccase enzymes. Pizzul et al., ${ }^{91}$ showed that purified laccase from fungi have an effect on glyphosate degradation. They concluded that in the presence of laccase and ABTS, $40.9 \%$ of the glyphosate disappeared after $24 \mathrm{~h}$, whereas $62.8 \%$ of the glyphosate was degraded when $\mathrm{Mn}^{2+}$ and Tween 80 were added together with the enzyme. Besides, Pizzul et al..$^{91}$ observed a synergistic effect of ABTS, $\mathrm{Mn}^{2+}$ and Tween 80 where $90.1 \%$ of glyphosate disappeared after $24 \mathrm{~h}$

\section{Pesticide solubilization by biosurfactants}

Once spread into the soil environment, pesticides quickly attach to the mineral and organic matter through a combination of physical, chemical and biological processes. Sorption, complexation, and precipitation constitute the main pesticide-soil interactions. The majority of pesticides are well known for their low aqueous solubility, high hydrophobicity and tendency to stay sorbed in soil..$^{33,92,93}$ Since water solubility of many organic contaminants is contributing to improving the mechanism removal, surfactants could be added to enhance their solubilization.

Surfactants are amphiphilic molecules structurally varied with two moieties, one hydrophilic and the other hydrophobic. The hydrophilic part generally formed by amino acids, peptides, cations, anions, mono, di or polysaccharides, while the hydrophobic portion is formed of saturated or unsaturated fatty acids. Surfactants are capable of reducing surface and interfacial tensions by accumulating at the interface of immiscible fluids and they can increase the solubility and mobility of hydrophobic or insoluble organic compounds. ${ }^{6}$ The presence of two functional groups in each molecule is a fundamental physical property of the surfactants, the latter property conditions the formation of micelles in solution by these types of compounds. When the surfactant concentration in water surpasses a certain level called the critical micelle concentration (CMC), surfactant molecule selfaggregate into a cluster known as micelles. ${ }^{94}$ The formation of micelles in solution gives surfactants their detergents and solubilization properties.

Surfactants, at concentrations above their CMC, have been shown to enhance solubilization of pollutants in soil and have been successfully used in soil washing or soil flushing for remediation of contaminated sites. ${ }^{694-96}$ The overuse of synthetic surfactants in soil remediation could represent an extra source of contamination and could have a serious effect on the ecosystem. ${ }^{97}$ For this reason, it is mandatory to replace them by biological surfactants generally called biosurfactants (BS) which are biodegradable and nontoxic relative to the synthetic surfactants. ${ }^{98}$ Additionally, BS could be produced from cheap raw materials and/or the organisms producing them could be genetically modified to overproduce or generate new compounds. ${ }^{98}$ Based on their chemical configuration, BS are classified as glycolipids, lipopeptides, phospholipids and lipopolysaccharides and are produced by diverse bacterial genera.

To improve soil bioremediation process, several researches were devoted to the isolation and characterization of novel surfactantproducing bacteria. On the other hand, they are focused on the use of BS products, which could solubilize and mobilize pesticide molecules on soil constituents. ${ }^{699}$ The most investigated BS in bioremediation are rhamnolipids, surfactine, lipopeptides and sophorolipids. ${ }^{6}$

Rhamnolipids are well-studied glycolipids with high potential in agriculture applications. ${ }^{100,101}$ They have the potential to be a part of alternative strategies to reduce or replace pesticides in agriculture. Nowadays, rhamnolipids plays a great importance for the effectiveness of new biopesticides. ${ }^{101}$ About 60 rhamnolipid congeners were described. ${ }^{102}$ Pseudomonas strains are among the best producers of glycolipid containing rhamnose and 3-hydroxy fatty acids. ${ }^{103-105}$ The most promising bacterial strain, P. aeruginosa, was investigated and advisable as the primary and the best microorganism to produce two classes of rhamnolipids known as monorhamnolipids and dirhamnolipids. ${ }^{104}$ Other Pseudomonas species have been also reported as rhamnolipid producers such as $P$. rhizophila, P. teessidea, P. stutzeri, P. putida, P. luteala, P. fluorescens, P. collierea, P. clemencea, $P$. chlorophis, $P$. cepacia, $P$. alcaligenes. ${ }^{76,102}$

The successful removal of pesticides by rhamnolipids under a variety of environmental conditions compared to synthetic surfactants was well reported. ${ }^{76,105-107}$ Mata-Sandoval and coworkers ${ }^{105,106}$ compared the efficiency of rhamnolipid and the synthetic nonionic surfactant Triton- $X$ to remove the pesticides trifluralin, coumaphos, and atrazine from soils with different clay, silt, and sand content. Pesticide solubilization depends on two factors, the first factor is the concentration of the micellar surfactant and the second one is the transportation of organic molecules from the true aqueous phase to a surfactant micellar pseudo-phase. Increased efficacy at concentrations above CMC, but none of the surfactants increased mobilization of pesticides at concentrations below the CMC, due to surfactant adsorption at the soil surface-water interface. The ability of synthetic surfactant to solubilize about twice as much of all pesticides as the rhamnolipid. This is due to the binding more tightly from pesticide to the BS micellar core and its diffusion out to the aqueous phase at a lower speed than that observed for the synthetic surfactant. On the other hand, Wattanaphon et al. ${ }^{107}$ proved that the use of glycolipid surfactants, produced by Burkholderia cenocepacia, was more efficient for the enhancement of three pesticides solubilization (i.e methyl parathion, ethyl parathion and trifluraline) than commercial surfactants (Tween 80 nonionic surfactant and SDS anionic surfactant).

\section{Conclusion}

The use of specific bacteria in the bioremediation process of some specific xenobiotic contaminant is considered as a topical issue in the area of environmental depletion. Pesticides are intensively and massively used in the modern agricultural practices. Pesticides 
remediation became necessary following their massive use in agricultural soils (with billiards of tons), and the bioremediation processes are preferred to the other physical-chemical ones. Bioremediation approaches are very cheap and with a relatively enduring efficacy. The genus Pseudomonas was taken as a microbial model due to the fact that the various bacteria constituting this genus are metabolically adaptable and able to degrade several and various organic or inorganic substances by producing enzymes and BS that can be used to enhance biodegradation rates.

\section{Acknowledgments}

None.

\section{Funding}

None.

\section{Conflicts of interest}

Authors declare that there is no conflict of interest.

\section{References}

1. Wilson C. Environmental and human costs of commercial agricultural production in South Asia. Int J Soc Economics. 2000;27:816-846.

2. Cycon M, Wójcik M, Piotrowska-Seget Z. Biodegradation of the organophosphorus insecticide diazinon by Serratia sp. and Pseudomonas sp. and their use in bioremediation of contaminated soil. Chemosphere. $2009 ; 76: 494-501$.

3. Chowdhury A, Pradhan S, Saha M, et al. Impact of pesticides on soil microbiological parameters and possible bioremediation strategies. Indian J Microbiol. 2008;48:114-127.

4. Kalia A, Gosal SK. Effect of pesticide application on soil microorganisms. Arch Agron soil Sci. 2011;57:569-596.

5. Riah W, Laval K, Laroche-Ajzenberg E, et al. Effects of pesticides on soil enzymes: a review. Environ Chem Lett. 2014;12:257-273.

6. Ortiz-Hernández ML, Sánchez-Salinas E, Dantán-González E, et al Pesticide biodegradation: mechanism, genetics and strategies to enhance the process. Biodegradation-Life Science. 2013:251-287.

7. Ahmad M, Akhta MFUZ, Jamil M, et al. Pesticide tolerant plant growthpromoting rhizobacteria isolated from rhizosphere of okra. Soil Environ. 2015;34:111-118

8. Gopalakrishnan S, Sathya A, Vijayabharathi R, et al. Plant growth promoting rhizobia: challenges and opportunities. 3 Biotech. 2015;5:355377.

9. Johnsen K, Jacobsen CS, Torsvik V, et al. Pesticide effects on bacteria diversity in agricultural soils-a review. Biol Fert Soils. 2001;33:443-453.

10. Qiu Y, Pang H, Zhou Z, et al. Competitive biodegradation of dichlobenil and atrazine coexisting in soil amended with a char and citrate. Environ Pollut. 2009;57:2964-2969.

11. Verma JP, Jaiswal DK, Sagar R. Pesticide relevance and their microbial degradation: a-state-of-art. Environ Sci Bio Technol. 2014;13:429-466.

12. Kahlon RS. Biodegradation and bioremediation of organic chemical pollutants by pseudomonas. In: Kahlon RS, editor. Pseudomonas: Molecular and Applied Biology. Springer international publishing; 2016:343-417.

13. Azaizeh H, Castro PM, Kidd P. Biodegradation of organic xenobiotic pollutants in the rhizosphere. Organic Xenobiotics and Plants. 2011:191215.
14. Kumar PG, Desai S, Leo Daniel Amalraj E, et al. Plant growth promoting pseudomonas spp. from diverse agro-ecosystems of india for sorghum bicolor L. J Biofert Biopest S. 2012.

15. Abo-Amer AE. Characterization of a strain of Pseudomonas putida isolated from agricultural soil that degrades cadusafos (an organophosphate pesticide). World J Microbiol Biotechnol. 2012;28:805-814.

16. Semen S, Mercan S, Acikkol M. A general overview of pesticides in soil: requirement of sensitive and current residue analysis methods. In: Kars $\mathrm{H}$, van den Eijkel L. editors. Soil in Criminal and Environmental Forensics. Soil Forensics. Springer; 2016:163-180.

17. Taylor EL, Holley AG, Kirk M. Pesticide development: a brief look at the history. Southern Regional Extension Forestry, Athens; 2007.

18. Muir P. A history of pesticide use. Oregon State University; 2012.

19. Wollersen H, Musshoff F. Chromatographic techniques for measuring organophosphorus pesticides. In: Bertholf RL, Winecker RE, editors. Chromatographic methods in clinical chemistry and toxicology. Chichester, UK: John Wiley \& Sons, Ltd; 2007.

20. Garcia FP, Ascencio SYC, Oyarzun JCG, et al. Pesticides: classification, uses and toxicity. Measures of exposure and genotoxic risks. $J$ Res Environ Sci Toxicol. 2012;1:279-293.

21. World Health Organization. The WHO recommended classification of pesticides by hazard and guidelines to classification 2009. Geneva, WHO; 2010

22. Gevao B, Semple KT, Jones KC. Bound pesticide residues in soils: a review. Environ Pollut. 2000;108:3-14.

23. Ecobichon DJ. Pesticide use in developing countries. Toxicol. 2001;160:27-33.

24. Afify A, Mohamed MA, El-Gammal HA, et al. Multiresidue method of analysis for determination of 150 pesticides in grapes using quick and easy method (QuEChERS) and LC-MS/MS determination. $J$ Food Agric Environ. 2010;8:602-606.

25. Sheet HGF. National pesticide information center. Corvallis, Oregon Oregon State University; 2009.

26. Deer HM. Pesticide adsorption and half-life. AG/Pesticides ; 1999;15:1.

27. Whitacre DM, Fernanda M, Gunther FA. Reviews of environmental contamination and toxicology. New York: Springer; 2012.

28. Kumar B, Kumar S, Gaur R, et al. Persistent organochlorine pesticides and polychlorinated biphenyls in intensive agricultural soils from North India. Soil Water Res. 2011;6:190-197.

29. Singh BK. Organophosphorus-degrading bacteria: ecology and industrial applications. Nat Rev Microbiol. 2009;7:156-164.

30. Pesticide Registration Service. Pesticides for agricultural use in Tunisia «Regulatory framework \& approval proCedure. Conference; 2017.

31. Pesticide Registration Service. List of pesticides approved in Tunisia 2018.

32. González-Delgado AM, Ashigh J, Shukla MK, et al. Mobility of indaziflam influenced by soil properties in a semi-arid area. PloS one. 2015;10:e 0126100

33. Arias-Estevez M, Lopez-Periago E, Martinez-Carballo E, et al. The mobility and degradation of pesticides in soils and the pollution of groundwater resources. ¿Agric Ecosyst Environ. 2008;123:247-260.

34. Lopez-Perez GC, Arias-Estevez M, Lopez-Periago E, et al. Dynamics of pesticides in potato crops. J Agric Food Chem. 2006;54:1797-1803.

35. John EM, Shaike JM. Chlorpyrifos: pollution and remediation. Chem Lett. 2015;13:269-291. 
36. Aktar W, Sengupta D, Chowdhury A. Impact of pesticides use in agriculture: their benefits and hazards. Interdiscip toxicol. 2009;2:1-12.

37. Abhilash PC, Singh N. Pesticide use and application: an Indian scenario. J hazard Mater. 2009;165:1-12.

38. Moorman TB, Jayachandran K, Reungsang A. Adsorption and desorption of atrazine in soils and subsurface sediments. Soil Sci. 2001;166:921-929.

39. Craven A, Hoy S. Pesticide persistence and bound residues in soilregulatory significance. Environ pollut. 2005;133:5-9.

40. Tiryaki O, Temur C. The fate of pesticide in the environment. $J$ Biol Environ Sci. 2010;4:29-38.

41. Arias-Estevez M, Soto-Gonzalez B, Lopez-Periago E, et al. Atrazine sorption dynamics in organic matter rich-soils. Bull Environ Contam Toxicol. 2005;75:264-271.

42. Arias-Estevez M, Torrente AC, Lopez-Periago E, et al. Adsorptiondesorption dynamics of cyprodinil and fludioxonil in vineyard soils. $J$ Agric Food Chem. 2005;53:5675-5681.

43. Lopez-Blanco C, Cancho-Grande B, Simal-Gandara J, et al. Transport of commercial endosulfan through a column of aggregated vineyard soil by a water flux simulating field conditions. J Agric Food Chem. 2005;53:6738-6743.

44. Chaplain V, Mamy L, Vieublé-Gonod L, et al. Fate of pesticides in soils: Toward an integrated approach of influential factors. In: Stoytcheva, M. (ed) Pesticides in the modern world-Risks and benefits. In Tech. 2011:535-560

45. Das P, Pal R, Chowdhury A. Influence of biotic-abiotic factors on the degradation of novaluron in tropical soil. Int J Environ Sci Technol. 2008:5:425-429.

46. Sevilla-Morán B, López-Goti C, Alonso-Prados JL, et al. Degradation of cyclohexanedione oxime herbicides. Herbicides-Advances in Research, InTech; 2013:101-130.

47. Spark KM, Swift RS. Effect of soil composition and dissolved organic matter on pesticide sorption. Sci Total Environ. 2002;298:147-161.

48. Loiseau L, Barriuso E. Characterization of the atrazine's bound (non extractable) residues using fractionation techniques for soil organic matter. Environ Sci Technol. 2002;36:683-689.

49. Mamy L, Barriuso E. Desorption and time-dependent sorption of herbicides in soils. Eur J Soil Sci. 2007;58:174-187.

50. Gevao B, Jones KC, Semple KT, et al. Peer reviewed: nonextractable pesticide residues in soil. Environ Sci Technol. 2003;37:138-144.

51. Odukkathil G, Vasudevan N. Toxicity and bioremediation of pesticides in agricultural soil. Environ Sci Bio Technol. 2013;12:421-444.

52. Forman S, Novák J, Tykva R, et al. Evaluation of toxicity of pesticides and their biodegradation products using human cells. Chemosphere. 2002;46:209-217.

53. Gunnell D, Fernando R, Hewagama M, et al. The impact of pesticide regulations on suicide in Sri Lanka. Int J Epidemiol. 2007;36:1235-1242.

54. Meyer A, Chrisman J, Moreira JC, et al. Cancer mortality among agricultural workers from Serrana Region, state of Rio de Janeiro, Brazil. Environ Res. 2003;93:264-271.

55. Mnif W, Hassine AIH, Bouaziz A, et al. Effect of endocrine disruptor pesticides: a review. Int J Environ Res. 2011;8:2265-2303.

56. Heys KA, Shore RF, Pereira MG, et al. Risk assessment of environmental mixture effects. RSC Advances. 2016;6:47844-47857.

57. Jokanović M. Medical treatment of acute poisoning with organophosphorus and carbamate pesticides. Toxicol Lett. 2009;190:107-115.
58. Binod PS, Bhupendra D. Obsolete pesticides: their environmental and human health hazards. J Agricul Environ. 2009;10:51-56.

59. Eddleston M, Street JM, Self I, et al. A role for solvents in the toxicity of agricultural organophosphorus pesticides. Toxicol. 2012;294:94-103.

60. Dawson AH, Eddleston M, Senarathna L, et al. Acute lethal human toxicity of agricultural pesticides: a prospective cohort study. PLoS Med. 2010;7:e1000357.

61. Salameh PR, Baldi I, Brochard P, et al. Respiratory symptoms in children and exposure to pesticides. Eur Respir J. 2003;22:507-512.

62. Sanchez-Pena LC, Reyes BE, Lopez-Carrillo L, et al. Organophosphorous pesticide exposure alters sperm chromatin structure in Mexican agricultural workers. Toxicol Appl Pharmacol. 2004;196:108-113.

63. Corsini E, Liesivuori J, Vergieva T, et al. Effects of pesticide exposure on the human immune system. Hum Exp toxicol. 2008;27:671-680.

64. Tebourbi O, Sakly M, Rhouma KB. Molecular mechanisms of pesticide toxicity. In: Stoytcheva M, editor. Pesticides in the Modern World-Pests Control and Pesticides Exposure and Toxicity Assessment. InTech; 2011:297-332.

65. Thabet H, Brahmi N, Kouraïchi N, et al. Intoxications par les pesticides organophosphorés: nouveaux concepts. Réanimation. 2009;18:633-639.

66. Singh BK, Walker A. Microbial degradation of organophosphorus compounds. FEMS microbiol reviews. 2006;30:428-471.

67. Boopathy R. Factors limiting bioremediation technologies. Biores Tech 2000;74:63-67.

68. Singh DK. Biodegradation and bioremediation of pesticide in soil: concept, method and recent developments. Indian J Microbiol. 2008;48:35-40.

69. Joutey NT, Bahafid W, Sayel H, et al. Biodegradation: involved microorganisms and genetically engineered microorganisms. Biodegradation-life of science. InTech; 2013:289-320.

70. Bertrand JC, Doumenq P, Guyoneaud R, et al. Applied microbial ecology and bioremediation. In: Bertrand JC, Caumette P, Lebaron P, editors Environmental microbiology: fundamentals and applications. Dordrecht: Springer; 2015:659-753.

71. Singh SN. Microbe-induced degradation of pesticides. Environ Sci. 2016.

72. Javaid MK, Ashiq M, Tahir M. Potential of biological agents in decontamination of agricultural soil. Scientifica. 2016;1598325.

73. Singh B, Mandal K. Bioremediation of pesticides in the environment. In: Singh B, Gosal SS, Arora R, editors. Biological and Molecular Approaches in Pest Management. Jadhpur, India: Scientific Publishers; 2015:73-96.

74. Yu YL, Chen YX, Luo YM, et al. Rapid degradation of butachlor in wheat rhizosphere soil. Chemosphere. 2003;50:771-774.

75. Krishnamoorthy V. Insecticide microbiology. In: Lal R, editor. Springer Science \& Business Media; 2012:1-260.

76. Hassen W, Neifar M, Cherif H, et al. Pseudomonas rhizophila S211, a new plant growth-promoting rhizobacterium with potential in pesticidebioremediation. Front microbial. 2018;9:34

77. Myresiotis CK, Vryzas Z, Papadopoulou-Mourkidou E. Biodegradation of soil-applied pesticides by selected strains of plant growthpromoting rhizobacteria (PGPR) and their effects on bacterial growth Biodegradation. 2012;23:297-310.

78. Zhuang X, Chen J, Shim H, et al. New advances in plant growth-promoting rhizobacteria for bioremediation. Environ Int. 2017;33:406-413.

79. Romeh AA, Hendawi MY. Bioremediation of certain organophosphorus pesticides by two biofertilizers, Paenibacillus (Bacillus) polymyxa (Prazmowski) and Azospirillum lipoferum (Beijerinck). J Agr Sci Tech. 2014;16:265-276 
80. Porto ALM, Melgar GZ, Kasemodel MC, et al. Biodegradation of pesticides. In: Stoytcheva M, editor. Pesticides in the modern worldpesticides use and management. InTech; 2011:407-438.

81. Pawar KR, Mali GV. Biodegradation of Quinolphos insecticide by Pseudomonas strain isolated from Grape rhizosphere soils. Int J Curr Microbiol App Sci. 2014;3:606-613.

82. Hussain S, Siddique T, Saleem M, et al. Impact of pesticides on soil microbial diversity, enzymes, and biochemical reactions. Adv Agron. 2009;102:159-200.

83. Ortiz-Hernández ML, Sánchez-Salinas E, Olvera-Velona A, et al. Pesticides in the environment: impacts and its biodegradation as a strategy for residue treatment. In: Stoytcheva M, editor. Pesticides formulations, effects, fate. Intech; 2011:978-953.

84. Lan WS, Cong J, Jiang H, et al. Expression and characterization of carboxylesterase E4 gene from peach-potato aphid (Myzus persicae) for degradation of Carbaryl and Malathion. Biotechnol Lett. 2005;27:11411146 .

85. Scott C, Pandey G, Hartley CJ, et al. The enzymatic basis for pesticide bioremediation. Indian J Microbiol. 2008;48:65-79.

86. Muthukumarasamy NP, Murugan S. Production, purification and application of bacterial laccase: a review. Biotechnol. 2014;13:196.

87. Maruyama T, Komatsu C, Michizoe J, et al. Laccase-mediated oxidative degradation of the herbicide dymron. Biotechnol Prog. 2006;22:426-430.

88. Torres-Duarte C, Roman R, Tinoco R, et al. Halogenated pesticide transformation by a laccase-mediator system. Chemosphere. 2009;77:687692.

89. Farragher N. Degradation of pesticides by the ligninolytic enzyme Laccase. 2013

90. Neifar M, Chouchane H, Mahjoubi M, et al. Pseudomonas extremorientalis BU118: a new salt-tolerant laccase-secreting bacterium with biotechnological potential in textile azo dye decolourization. 3 Biotech. 2016;6:1-9.

91. Pizzul L, del Pilar Castillo M, Stenström J. Degradation of glyphosate and other pesticides by ligninolytic enzymes. Biodegradation. 2009;20:751759 .

92. Đurović R, Gajić-Umiljendić J, Đorđević T. Effects of organic matter and clay content in soil on pesticide adsorption processes. Pesticidi $i$ fitomedicina. 2009;24:51-57.

93. Salem DMA, Khaled A, El Nemr A. Assessment of pesticides and polychlorinated biphenyls (PCBs) in sediments of the Egyptian Mediterranean Coast. Egypt J Aquat Res. 2013;39:141-152.

94. Cirelli AF, Ojeda C, Castro MJ, et al. Surfactants in sludge-amended agricultural soils: a review. Environ. Chem Lett. 2008;6:135-148.

95. Katagi T. Surfactant effects on environmental behavior of pesticides Reviews of environmental contamination and toxicology. 2008:71-177.

96. Bustamante M, Durán N, Diez MC. Biosurfactants are useful tools for the bioremediation of contaminated soil: a review. J Soil Sci Plant Nutr. 2012;12:667-687.

97. Ying GG. Fate behavior and effects of surfactants and their degradation products in the environment. Environment internationals. 2006;32:417431.

98. Reis RS, Pacheco GJ, Pereira AG, et al. Biosurfactants: production and applications. In: Chamy R, editor. Biodegradation: life of science. Rijeka, Croatia: InTech; 2013:978-953.

99. Albino JD, Nambi IM. Effect of biosurfactants on the aqueous solubility of PCE and TCE. J Environ Sci Health. 2009;44:1565-1573.

100. Sachdev DP, Cameotra SS. Biosurfactants in agriculture. Appl Microbiol Biotechnol. 2013;97:1005-1016.
01. Sinumvayo JP, Ishimwe N. Agriculture and food applications of rhamnolipids and its production by Pseudomonas aeruginosa. J Chem Eng Process Technol. 2015;6:223.

102. Abdel-Mawgoud AM, Lépine F, Déziel E. Rhamnolipids: diversity of structures, microbial origins and roles. Appl Microbiol Biotechnol. 2010;86:1323-1336.

103. Gunther NW, Nunez A, Fett W, et al. Production of rhamnolipids by Pseudomonas chlororaphis, a nonpathogenic bacterium. Appl Environ Microbiol. 2005;71:2288-2293.

104. Müller MM, Hörmann B, Kugel M, et al. Evaluation of rhamnolipid production capacity of Pseudomonas aeruginosa PAO1 in comparison to the rhamnolipid over-producer strains DSM 7108 and DSM 2874. Appl Microbial biotechnol. 2011;89:585-592.

105. Mata-Sandoval JC, Karns J, Torrents A. Effect of rhamnolipids produced by Pseudomonas aeruginosa UG2 on the solubilization of pesticides. Environ Sci technol. 2000;34:4923-4930.

106. Mata-Sandoval JC, Karns J, Torrents A. Effect of nutritional and environmental conditions on the production and composition of rhamnolipids by P. aeruginosa UG2. Microbiological research. 2001;155:249-256.

107. Wattanaphon HT, Kerdsin A, Thammacharoen C, et al. A biosurfactan from Burkholderia cenocepacia BSP3 and its enhancement of pesticide solubilization. J Appl Microbial. 2008;105:416-423.

108. Kamanavalli CM, Ninnekar HZ. Biodegradation of DDT by a Pseudomonas species. Current Microbiol. 2004;48:10-13.

109. Wang L, Chi XQ, Zhang JJ, et al. Bioaugmentation of a methyl parathion contaminated soil with Pseudomonas sp. strain WBC-3. Int Biodeterior Biodegr. 2014;87:116-121.

110. Nawab A, Aleem A, Malik A. Determination of organochlorine pesticides in agricultural soil with special reference to $\gamma-\mathrm{HCH}$ degradation by Pseudomonas strains. Biores technology. 2003;88:41-46.

111. Chanika E, Georgiadou D, Soueref E, et al. Isolation of soil bacteria able to hydrolyze both organophosphate and carbamate pesticides. Biores Technol. 2011;102:3184-3192.

112. Hassen W, Neifar M, Cherif H, et al. Assessment of genetic diversity and bioremediation potential of pseudomonads isolated from pesticidecontaminated artichoke farm soils. 3 Biotech. 2018;8:263.

113. Sarah S, Murthy VK, Riaz M. Characterization of Endosulfan and Endosulfan sulphate degradation by strains of Pseudomonas putida. Int $J$ Env Sci. 2012;3:859-869.

114. Nazarian A. Utilization of dimethoate by wild type Pseudomonas putida from polluted sites in Iran. Pak J Bio Sci. 2007;10:664-667.

115. Deshpande NM, Dhakephalkar PK, Kanekar PP. Plasmid-mediated dimethoate degradation in Pseudomonas aeruginosa MCMB- 427. Lett Appl Microbiol. 2001;33:275-279.

116. Lakshmi CV, Kumar M, Khanna S. Biotransformation of chlorpyrifos and bioremediation of contaminated soil. Int Biodeterior Biodegr. 2008;62:204-209.

117. Narkhede CP, Patil AR, Koli S, et al. Studies on endosulfan degradation by local isolate Pseudomonas aeruginosa. Biocatal Agric Biotechnol. 2015;4:259-265.

118. Al-Arfaj A, Abdel-Megeed A, Ali HM, et al. Phyto-microbial degradation of glyphosate in Riyadh area. J Pure App Microbio. 2013;7:1351-1365.

119. Saikia N, Das SK, Patel BK, et al. Biodegradation of beta-cyfluthrin by Pseudomonas stutzeri strain S1. Biodegr. 2005;16:581-589.

120. Bhadbhade BJ, Dhakephalkar PK, Sarnaik SS, et al. Plasmid-associated biodegradation of an organophosphate pesticide, Monocrotophos, by Pseudomonas mendocina. Biotechnol lett. 2002;24:647-650. 
121. Hassanshahian M, Shahi Z. Isolation and characterization of endosulfandegrading bacteria from contaminated agriculture soils. J Coastal Life Med. 2016;4:290-294.
122. Mahiudddin M, Fakhruddin ANM, Al-Mahin A, et al. Degradation of the organophosphorus insecticide diazinon by soil bacterial isolate. Int $J$ biotech. 2014;3:12-23. 